\title{
INFLUENCE OF SOWING TIME PRODUCTIVITY OF GREEN MASS OF SUDAN GRASS DRY STEPPE ZONE IN NORTHERN KAZAKHSTAN
}

\author{
N.Serekpaev ${ }^{1}$, S.Seifullin ${ }^{2}$, A.Nogayev ${ }^{3}$, S.Bekbulatov ${ }^{3}$, \\ B.Dorj ${ }^{3}$, L.Batmunkh ${ }^{3}$, B.Batdelger ${ }^{3}$ \\ 1-Kazakh Agrarian Technical University \\ 2-Astana Kazakhstan \\ 3-Mongolian State University of Agriculture, Ulaanbaatar \\ adilbek_nogaev@mail.ru
}

\begin{abstract}
In this article we analyze the effect of sowing date on yield of Sudan grass green mass. The study was conducted over 2 years on the basis of working farms in the dry steppe zone of Kazakhstan. The yield of Sudan grass green mass is depending on the most favorable sowing dates.
\end{abstract}

KEYWORDS: sudan grass, variety Brodskaya 2, green mass, sowing dates, precipitation, the hydrothermal coefficient.

\section{INTRODUCTION}

The problem of ensuring food self-sufficiency the Republic of Kazakhstan and production of competitive agricultural products, to be held President N.A. Nazarbayev, at the beginning of the century (1), becomes more urgent after the country's accession to the SES, and in the near future in the WTO, which "produces special requirements for competitiveness of domestic products in the first place - dairy and meat" (2). One of the main directions in solving the problem - reducing the cost of livestock production and increase productivity in the industry, which

\section{OBJECTS AND METHODS}

The studies were conducted in the dry zone of the Akmola region in 2011-2012 and based on a large farm LLP "Baimyrza - Agro". The experimental site is located on the southern chernozem. Soil samples for the determination of humus, nutrients, and $\mathrm{pH}$ were selected from the layers 0 - depends on the quality, quantity, value, given that the structure of production costs at least $50 \%$ is the cost of feed, to the a low productivity of animals cannot rely on low cost milk and meat, as well as the low yield of fodder crops for their low cost (3).

In this connection the study of the elements of technology of cultivation of annual cereal crops adapted to the specific soil and climatic zones of the republic is one of the important directions of research.

$20,20-40,40-60 \mathrm{~cm}$ by depth, and the chemical analyzes were performed in the laboratory of the State Institution "Republican Scientific and Methodological Center agrochemical service" (Table 1). 
Table 1

The performances of soil analysis on humus, soil nutrients $\left(\mathrm{N}, \mathrm{P}_{2} \mathrm{O}_{5}, \mathrm{~K}_{2} \mathrm{O}\right)$, $\mathrm{pH}$ by soil layers

\begin{tabular}{lccccc}
\hline \multirow{2}{*}{$\begin{array}{c}\text { Soil layer } \\
\text { (horizon),sm }\end{array}$} & $\mathrm{N}$ & $\mathrm{P}_{2} \mathrm{O}_{5}$ & $\mathrm{~K}_{2} \mathrm{O}$ & Humus & $\mathrm{pH}$ \\
\cline { 2 - 6 } & \multicolumn{3}{c}{$\%$} \\
$0-20$ & 38,1 & $\mathrm{mg} / \mathrm{kg}$ of soil & 5,18 & 6,95 \\
$20-40$ & 30,0 & 7,1 & 480 & 2,91 & 7,31 \\
$40-60$ & 27,0 & 2,3 & 214 & 2,26 & 7,37 \\
\hline
\end{tabular}

In the experiment were studied the effects of three sowing dates (first, second decade of May, the first decade of June) on the formation of green mass yield of Sudan grass. There used for sowing approved for planting Sudan grass variety Brodskaya 2. The size of one plot was $126 \mathrm{~m}^{2}$ and it replicated 3 times. The total size of experimental plots are taken 0,12 ha. The experimental study has done by the methods of B.A. Dospehov, and methodology with GSI for crops $[4,5]$.

In the experiments were used a common technology for the area of cultivation of Sudan grass. All technological operations in the experiment field, except sowing dates were the same.

In autumn after harvesting a previous crop (spring wheat) have been calculated doses of mineral phosphate fertilizers (ammophos, $194 \mathrm{~kg}$ /ha a.s.) followed by deep tillage to a depth of 22 $\mathrm{cm}$. In the spring before sowing drills C3C- 2,1 were made nitrogen fertilizers (ammonium nitrate - $45 \mathrm{~kg} / \mathrm{ha}$ a.s.) to a depth of $10 \mathrm{~cm}$ Sudan grass seeds sown drill C3C-2,1 seeding rate $18 \mathrm{~kg} /$ ha (2 million seeds/ha) to a depth of $5 \mathrm{~cm}$.

During the growing season in all variants of the experiment was carried out an eradication of weeds. Weed infestation for all variants in the experimental field was estimated by the gravimetric method, indicating the species composition of weeds by the method of B.A. Dospehov. By imposing on $0,25 \mathrm{~m}^{2}$ frames at four locations along the diagonal of the plots in the 6-fold replication were determined. Accounting weeds was carried out on 1 and 3 repeated experiments. Weeds were counted and weighed separately by type to air-dry condition in accordance with the methodology.

Harvesting took a place in phase hay harvest maturity (buttonhole) mowing. Harvest measurements are taken in $100 \mathrm{~m}^{2}$ area by cutting and weighing the green mass with each plot.

In 2011, the daily average temperature the air passage through the $0^{\circ} \mathrm{C}$ was recorded at the the first decade of April, and the average temperature through the transition $+10^{\circ} \mathrm{C}$ was observed the second decade of May. The sum of active temperatures (above $+10^{\circ} \mathrm{C}$ ) during the growing season of plants (seedlings - hay harvest ripeness) was $879^{\circ} \mathrm{C}$. The mean daily air temperature between May and June by $1,4^{\circ} \mathrm{C}$ were lower in July and August at $3,8-4,0^{\circ} \mathrm{C}$ above (Figure 1). In 2012, the average daily temperature in comparison with 2011 was higher. Transition average daily air temperature over $0^{0}$ was recorded in early April. Home heating temperature to $+6-8^{0} \mathrm{C}$ started at the end of the first decade of April, the average temperature through the transition from $+10^{\circ} \mathrm{C}$ in second decade of April. The sum of active temperatures during the growing season (shoots - hay harvest ripeness) was $-1352^{\circ} \mathrm{C}$, shoots - full ripeness of seeds $-2121^{\circ} \mathrm{C}$. 


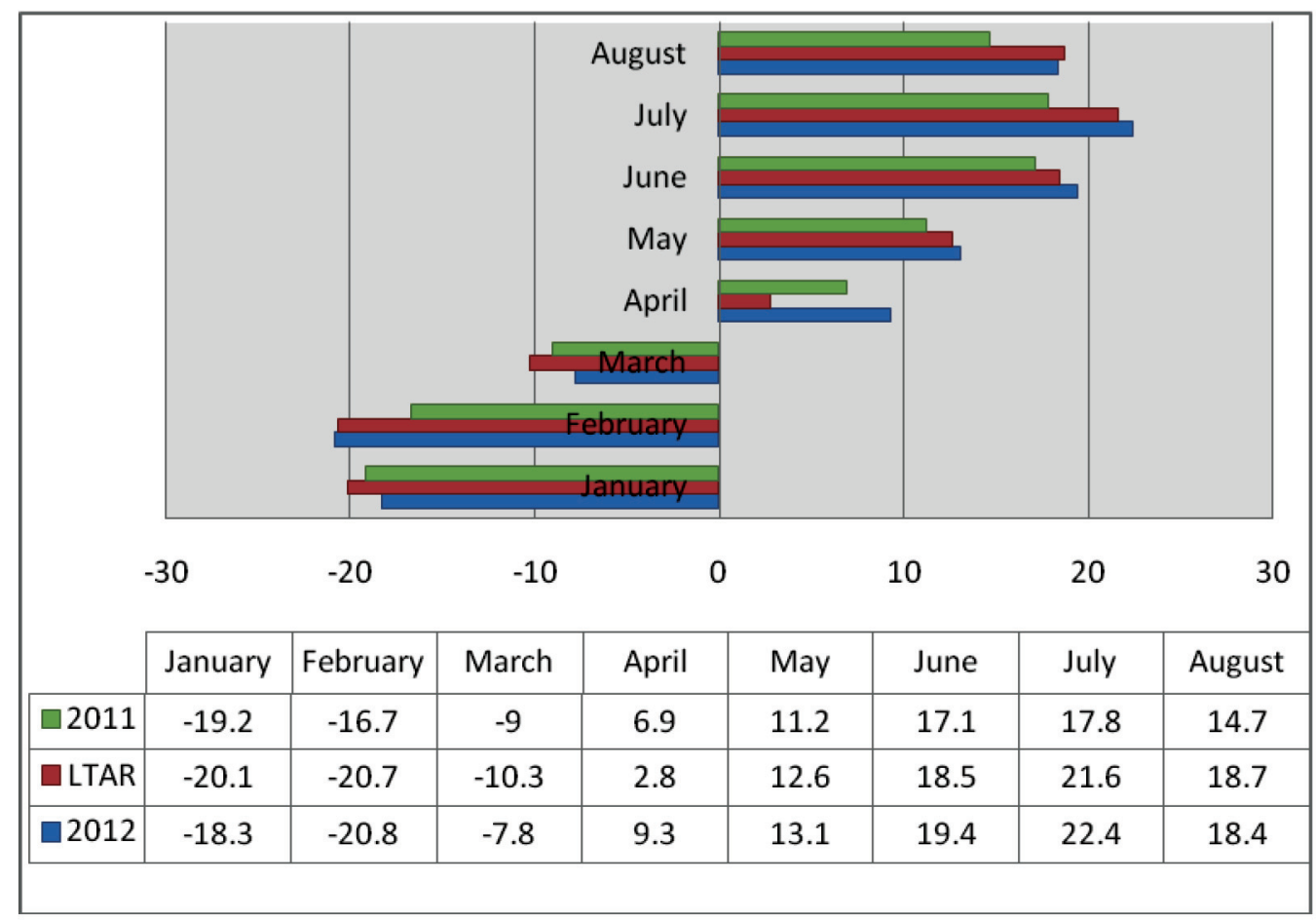

Figure 1. The average temperature in 2011-2012 comparing to the average long-term indicator, ${ }^{\circ} \mathrm{C}$.

In 2011, the maximum amount of precipitation during the warm period fell in June; July $1.5-2.0$ times, and in the rest of the year was slightly lower or at the average annual rate. In 2012, the amount of precipitation for the month of the growing season was below the average long-term indicators in 1.5-2.0 times lower (Figure 2).

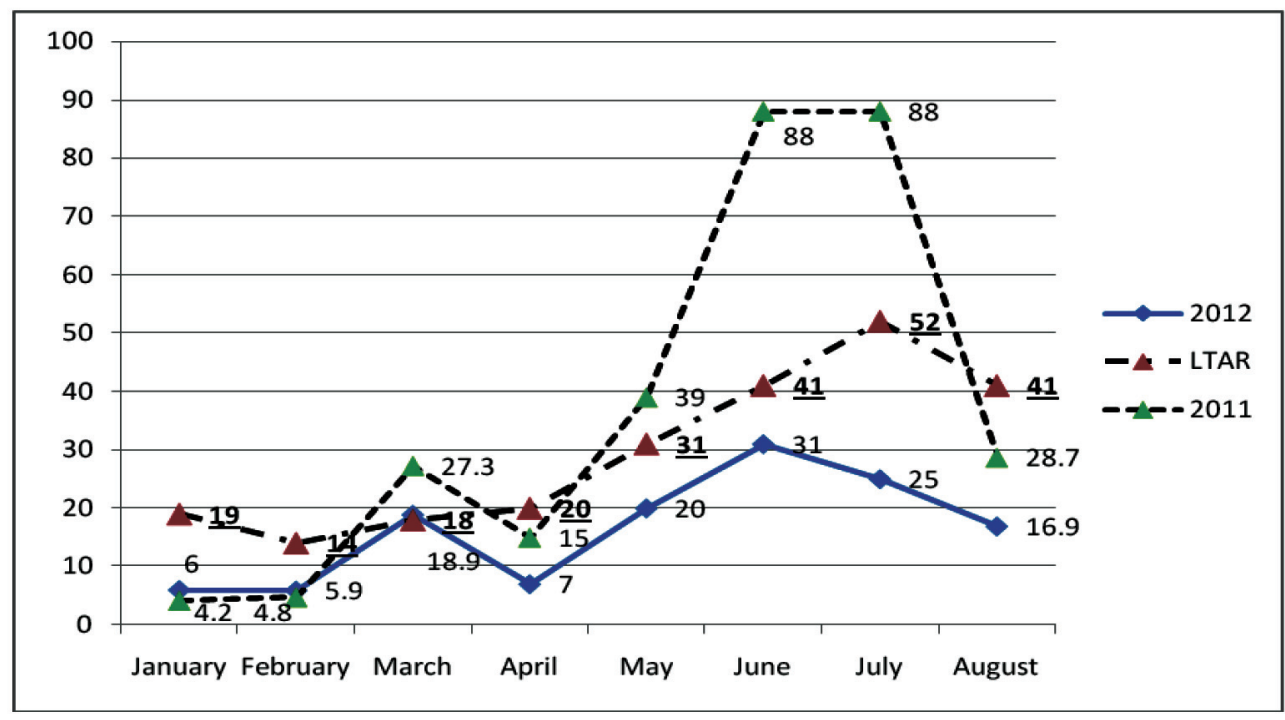

Figure 2. The rainfall in 2011-2012 compared to the long-term average, $\mathrm{mm}$

In assessing the level of moisture in the region should consider the hydrothermal coefficient (SCC) on G.T. Selyaninov which is determined by the ratio total rainfall $(\mathrm{r})$ in $\mathrm{mm}$ for the period with average daily temperatures above $10^{\circ} \mathrm{C}$ to the sum of temperatures $(\Sigma \mathrm{t})$ for the same period decreased by 10 times:

$$
H T C=\frac{r}{0,1 \sum t} \cdot[6]
$$


Calculation of hydrothermal coefficient (SCC) on G.T. Selyaninov was based on analysis of meteorological conditions prevailing in 2011-2012 according to the weather station in Stepnyak in

Enbekshilder district of Akmola region.

Calculation of the SCC for 2011-2012

\begin{tabular}{cccc}
\hline Years & $\begin{array}{c}\text { Total precipitation }(\mathrm{r}) \text { in } \mathrm{mm} \\
\text { for the period with average } \\
\text { daily temperatures above } \\
10^{\circ} \mathrm{C}\end{array}$ & $\begin{array}{c}\text { The sum of temperatures }(\Sigma \mathrm{t}) \text { at }{ }^{0} \mathrm{C} \\
\text { for the period with average daily } \\
\text { temperatures above } 10^{\circ} \mathrm{C} \text {, reduced } \\
\text { to ten times }\end{array}$ & $\begin{array}{c}\text { Hydrothermal } \\
\text { coefficient }(\mathrm{SCC}) \text { on } \\
\text { G.T. Selyaninov }\end{array}$ \\
\hline 2011 & 95,9 & 2114 & 1,1 \\
2012 & 244,5 & 2379 & 0,4 \\
\hline
\end{tabular}

Thus, conditions in 2011 are characterized as favorable indicator of SCC - 1.1, and in 2012 a very severe drought SCC - 0, 4.

\section{RESULTS AND DISCUSSION}

The field germination of seeds of Sudan grass by the average for 2 years ranged from 55 to $64 \%$ (Table 3).

Field germination and plant population, depending on the time of sowing,

Table 3

By the average in 2011-2012

\begin{tabular}{|c|c|c|c|c|c|c|c|c|c|c|c|c|c|}
\hline \multirow{2}{*}{$\begin{array}{c}\text { Sowing } \\
\text { dates }\end{array}$} & \multirow{2}{*}{$\begin{array}{c}\text { Seeding } \\
\text { rate } \\
\omega \mathrm{\omega} / \mathrm{M}^{2}\end{array}$} & \multicolumn{3}{|c|}{$\begin{array}{l}\text { The number of } \\
\text { plants in the } \\
\text { phase of full } \\
\text { germination } \\
\text { items } / \mathrm{m} 2\end{array}$} & \multicolumn{3}{|c|}{ Germination, $\%$} & \multicolumn{3}{|c|}{$\begin{array}{l}\text { The number of } \\
\text { plants for } \\
\text { harvest, } \\
\text { pcs./m2 }\end{array}$} & \multicolumn{3}{|c|}{$\begin{array}{l}\text { Capacity of } \\
\text { survival, \% }\end{array}$} \\
\hline & & $\overline{\vec{\sigma}}$ & $\stackrel{\sim}{\stackrel{2}{2}}$ & 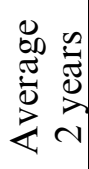 & $\overrightarrow{\vec{i}}$ & 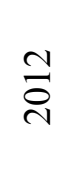 & 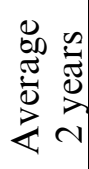 & $\overline{\vec{i}}$ & $\stackrel{ }{\stackrel{2}{2}}$ & 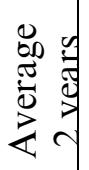 & $\bar{\Xi}$ & 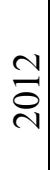 & 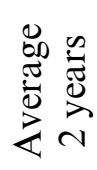 \\
\hline $\begin{array}{l}\text { May } 21 \\
\text { (1 period of } \\
\text { sowing) }\end{array}$ & 200 & 117 & 104 & 111 & 58 & 52 & 55 & 101 & 84 & 62 & 86 & $\begin{array}{l}8 \\
0\end{array}$ & 83 \\
\hline $\begin{array}{c}\text { May } 30 \\
\text { (2 period of } \\
\text { sowing) }\end{array}$ & 200 & 153 & 104 & 129 & 76 & 52 & 64 & 147 & 89 & 79 & 96 & $\begin{array}{l}8 \\
5\end{array}$ & 91 \\
\hline $\begin{array}{l}10 \text { June } \\
\text { (3 period of } \\
\text { sowing) }\end{array}$ & 200 & 139 & 107 & 123 & 69 & 53 & 61 & 127 & 77 & 68 & 91 & $\begin{array}{l}7 \\
2\end{array}$ & 82 \\
\hline
\end{tabular}

By average of 2 years on all terms of sowing Sudan grass dominated annual weeds, the largest number of which were accounted for 99 barnyard millet and foxtail items $/ \mathrm{m}^{2}$ bluish items $/ \mathrm{m}^{2}$ to 116 (Table 4). 
Infestation Sudan grass plants depending on different sowing dates, $\mathrm{pcs} . / \mathrm{m}^{2}$

\begin{tabular}{lcccccc}
\hline Types of weeds & $\begin{array}{c}\text { 1 sowing } \\
\text { date } \\
\text { (May 21) }\end{array}$ & in\% of total & $\begin{array}{c}\text { 2 sowing } \\
\text { date } \\
\text { (May 30) }\end{array}$ & in\% of total & $\begin{array}{c}\text { 3 sowing } \\
\text { date } \\
\text { (June 10) }\end{array}$ & $\begin{array}{c}\text { in\% of } \\
\text { total }\end{array}$ \\
\hline total: & 241,5 & 100 & 204,5 & 100 & 146,8 & 100 \\
field bindweed & 15 & 6,2 & 8,5 & 4,2 & 1 & 0,7 \\
barnyardgrass & 99 & 40,9 & 93 & 45,5 & 42,8 & 29,1 \\
foxtail dove & 116 & 48,0 & 97,5 & 47,7 & 101 & 68,8 \\
Shiritsa upturned & 6 & 2,5 & 3,5 & 1,7 & 1 & 0,7 \\
Other & 5,5 & 2,3 & 2 & 1 & 1 & 0,7 \\
\hline
\end{tabular}

Note to other classified molokans tatar, lozny spurge, common lambs quarters, etc.

Top hay harvest ripeness (phase buttonhole) Sudan grass plant height in 2011, reached the first sowing date $-87 \mathrm{~cm}$, in the second term of sowing $-137 \mathrm{~cm}, 158 \mathrm{~cm}$ in the third face of the current year by $65,6 \mathrm{~cm}, 70,6 \mathrm{~cm}, 18,2 \mathrm{~cm}$.

Depending on the prevailing meteorological conditions and sowing the highest yield of green mass of Sudan grass in 2011 was formed at late planting dates (June 10) 9,8 t/ha, and the smallest at the first sowing date (May 21) - 5,4 t/ha, and in 2012 the highest yield of green mass was the constitution of the second sowing date (May 30) 2,0 t/ha (table 5).

Yield of green mass of Sudan grass, depending on sowing date, $t /$ ha

\begin{tabular}{lccc}
\hline \multicolumn{1}{c}{ sowing dates } & \multicolumn{3}{c}{ Years } \\
\cline { 2 - 4 } & 2011 & 2012 & $\begin{array}{c}\text { Average for } \\
\text { two years }\end{array}$ \\
\hline 1st sowing date (21 May) Control, & 5,4 & 1,5 & 3,5 \\
recommended for the zone sowing date & 7,5 & 2,0 & 4,8 \\
$2^{\text {nd }}$ sowing date (30 May) & 9,8 & 1,0 & 5,4 \\
Third sowing date (10 June) & 6,9 & 3,7 & 3,5 \\
LSD $_{05}$ & & \\
\hline
\end{tabular}

The share of the influence of meteorological conditions on the formation of green mass yield

\section{CONCLUSION}

In the dry steppe zone of the Akmola region, depending on the prevailing weather conditions by mean for the two-year study, the highest yield of green mass of Sudan grass $5,4 \mathrm{t} /$ ha was of Sudan grass were $70 \%$ and $30 \%$ from sowing date.

\section{REFERENCE}

1. Назарбаев Н.А. Об основных направлениях внутренней, внешней политики на 2003 г. Послание Президента народу Казахстана. Астана 2002 г.

2. Назарбаев Н.А. Выступление на внеочередном съезде Народной партии «Нур Отан», Казахстанская правда, 16 мая 2009 г.

3. Серекпаев Н.А., Стыбаев Г.Ж. Состояние observed in the third period of sowing in early June, with the bulk of up to $70 \%$ on the formation green mass yield had meteorological conditions and $30 \%$ of sowing.

Table 5 